\title{
An Empirical Study of the Everyday Life Information Seeking Behavior of the Baby-boomers as Pre-retirees"
}

\author{
베이비붐세대 은퇴예정자의 정보이용행태에 관한 연구
}

\author{
Mi Hyang Park** \\ Jee Yeon Lee***
}

\begin{abstract}
This study presents the findings from research on the Everyday Life Information Seeking (ELIS) behaviors of Korean government officials in their 50s. 500 survey respondents participated and the quantitative data were analyzed through Structural Equation Model having six key concepts such as personal information environment, information-seeking attitudes, online information attitudes, barriers to information seeking, retirement expectations, and library expectations. The findings showed the important relationships between expectations of the retirement and two constructs (personal information environment and information-seeking attitudes). This study can be used as a strategic implication for library practitioners to develop their library management process in accordance to the potential and powerful evolving user group in a future aged society.
\end{abstract}

\section{초 록}

본 연구는 50 대 공직자 500 명의 일상에서의 정보탐색행태와 패턴을 탐색하고자 하였다. 구조방정식을 활용한 설문자료분석은 은퇴예정집단으로서 베이비붐세대의 개인정보환경, 개인정보추구태도, 온라인정보태도, 정보추구 의 장애, 은퇴기대와 도서관기대라는 6 개의 변수간의 상호 연관관계 모형을 보여주고 있다. 그 중 개인정보환경과 정보추구태도는 은퇴기대와 유의미한 관계가 있음을 입증하였다. 이 연구결과는 노령사회를 대비하여 새롭게 부상하 게 될 도서관이용자집단에 대한 도서관정책개발의 기초자료로 활용될 수 있을 것이다.

Keywords: pre-retirees, baby-boomer, baby-boom generation, retirement expectation, library expectation, everyday life information seeking behavior, ELIS 은퇴예정자, 베이비붐세대, 베이비부머, 은퇴기대, 은퇴준비, 도서관기대, 정보행태

* This research was based on the Doctorate dissertation of Mi Hyang Park.

** Director of Planning Division, National Assembly Library of Korea(npoya@nanet.go.kr)

*** Associate Professor, Department of Library and Information Science, Yonsei University (jlee01@yonsei.ac.kr)

- Received : 17 May 2011 - Revised : 24 May 2011 - Accepted : 3 June 2011

- Journal of the Korean Society for Information Management, 28(2): 195-208, 2011.

[DOI:10.3743/KOSIM.2011.28.2.195] 


\section{Introduction}

In Korea, the postwar baby-boom generation, born between 1955 and 1963, reached the retirement age beginning the year of 2010 . According to several articles, only $13.9 \%$ of baby boomers have some positive expectations on their retirement lives (Lee 2009) and retirement events in life could have negative influences on the psychological condition of people (Gee and Baillie 1999; Fretz et al. 1989; Lee 2003; Han 2002). In this social change, even though there have been active discussions on the impacts of the aging society, there have not been many user studies to find the information seeking behavior of those preparing for retirement. The increasing problems of aging presents an opportunity to rethink the social and personal lives of baby boomers in order to ensure the possibility and welfare of each individual heading towards a more productive and active older generation.

The demographic shift caused from baby boomers' retirement will see an increase in the number of retirees with higher education as well as an increase of the average life span. They will seek to continue the quality level of life and social activities after their retirement. Recognizing and treasuring the contribution of the baby-boom generation is essential to the long-term flourishing of society. In this context, we assume that baby boomers will have unique information needs to determine the types of the social activities in which to participate even after they retire. Thus, the objective of this research was to investigate the information seeking behavior of baby boomers, to find the relationship between the retirement expectation and some library expectation, and to get implication of future library service in the aged society.

\section{Literature Review and Model Formulation}

\subsection{Key constructs of information-seeking behavior of the boomers}

\section{- Personal information environment}

Information-seeking does not occur in isolation from one's surroundings. These surroundings encompass a wide variety of factors that influence people's information behavior (Hargittai and Hinnant 2006). Dervin (1992) describes the patterns of everyday living move an individual forward in his or her own space-time continuum, but there are stops in this space-time continuum that are caused by cognitive discontinuities-information needing or gaps. Bridging these gaps in our daily lives requires information to make sense of the whole.

In this sense, receiving information is identified as a process of adaptation or coping with the information environment (Nahl 2007). The availability of various resources, whether physical or social, and the special situations and expectation of participants should be included in parts of the conceptual framework of research to explore the nuances of personal environment and information behavior of the baby-boomers. 
Information can be identified by the information seeker who attends, on both an unconscious and conscious levels, to the stimuli and behavioral models in her or his environment (Jopsen 1989). In this understanding of personal information environment, the researcher focused on the spatial and time factors as significant indicators to explain the personal information environment in the survey setting.

\section{- Information-seeking attitudes}

Attitudes have long been a major area of investigation in psychology, especially as a predictor of future behavior (Fretz et al. 1989). Usually information used by persons in making decisions about their future lives includes attitudes and beliefs instilled during socialization, and in school, and specific information provides by any number of sources (Julien 1999). In most cases, people are only motivated to seek information when they both know that they are ignorant and the missing information be salient.

In this context of information seeking behavior, the researcher could anticipate that human information attitudes were diversified based on personal interesting fields, patterns of information resources usage, type of social interaction, personal expectation and preparation of future. In this assumption of information-seeking patterns, the researcher explored the sensitivity of personal interests and preparation of future uncertainty in personal life context as the significant items of survey to reveal personal level of information-seeking attitudes.

\section{- Online information attitudes}

People now search mobile systems, real-time systems, and interactive systems in the home or the office. People live in the world where the proliferation of personal computers, the growth of the internet, and the accompanying development of information and communication services provide people with access to many new services and potential new channels of information access (Spink and Cole 2001).

Thus, the researcher chose the valuation of web information and the autonomy of online information use as the significant indicators to show the patterns of personal information searching in survey setting. Another indicator is the usefulness of Web information perceived by person. According to Davis (1989), perceived usefulness is defined as the degree to which a person believes that using a particular system would enhance his or her performance.

\section{- Barriers to information seeking}

The human information condition is often marked by frustration and a lack of understanding when people engage in information behavior, which result in the cause of information seeking failure. To see the boomers suffer when seeking information for the after-retirement period in everyday life context, the researcher needed to give special attention on the barrier-oriented research. The overall focus of research in this field is a description of barriers to information access. Such research starts with a particular receiver's problem, then locates and examines the difficulties in accessing and using the sources of information that will solve the problem (Spink 
and Cole 2001). In this context, the researcher tried to identify the barriers perceived by the boomers as they seek to prepare for the after-retirement life. A barrier is the factor preventing certain population in society from gaining information access to them. In other words, mere availability of information neither equal accessibility, nor does it provide a realistic chance that people may come across the types of information of most interest or use to them (Spink and Cole 2006).

Increasing diversity of information through communication technologies could be lead to overload. What is perceived as information overload may be work overload. According to Bawden and Robinson (2009), 'too much information' may actually reflect 'too much to do', 'too much activity', or 'too many diverse duties.' Thus, the researcher included the perceived work overload and information overload which had influence on personal barriers to seeking information.

\section{- Expectations of the retirement}

The previous research in both England and Australia has shown that positive attitudes toward retirement were the significant predictors of subsequent adjustment in retirement (Atton 1985; Gee and Baillie 1999). Retirement expectations include hope for future life after retirement such as wanting to remain independent and healthy and to have time to socialize and travel (Hunter, Wang, and Worsley 2007). In developing of concept of the retirement expectations, the researcher needed to more focus on the information seeking life in which people could socialize with other people and broaden the intellectual scopes of personal interests for in-depth understanding of information-seeking behavior.

There have been compared opinions and expectations of retirement life in the research(Oldenburg 1999; Gee and Baillie 1999; Fretz et al. 1989; Lee 2003; Han 2002). And the increasing problems of aging present an opportunity to rethink the social and personal lives of baby boomers in order to ensure the possibility and welfare of each individual heading toward more productive and active older generation.

\section{- Expectations on the libraries}

This construct was developed based on expected service performance of the LibQUAL+TM on the three key dimensions of library such as affect of service, service control, and physical place. Evolved from SERVQUAL measurement from business area, LibQUAL+TM, among the user-based evaluation tools, is the most widely used evaluation criteria for library service (Cook and Heath 2001).

Even though the perceptive assessment of library service by the users in the LibQUAL+TM was important for evaluation of library, in this research, it was not that significant factor because most boomers in mid-life were the latent user group for now, who would be the powerful group in library after retirement. Therefore, the researcher gave more values on the library expectations of baby-boomer as their alternative public place after retirement, rather than perceived library service, and assessed this factor through measurement of three different aspects of library place. 


\subsection{Model and hypotheses development}

The researcher tried to find that the framework served the primary purpose of the research and the suggested framework showed the relationships between some of the individual and contextual factors that would influence the baby-boomers' expectations of retirement and library. Figure 1 illustrates the key constructs of hypotheses and the relationships between each factor.

Based on the theoretical background of literature review, the researcher established the conceptual framework visualizing hypotheses on the relationships of six key constructs and then, five hypotheses (Hs) related to the ELIS behavior of the pre-retirees were developed and tested.

H1: Personal information environment has influence on the retirement expectations.

$\mathrm{H} 2$ : Information-seeking attitudes have influence on the retirement expectations.

H3: Online information attitudes have influence on the library expectations.
H4: Barriers to information seeking have influence on the library expectations.

H5: The retirement expectations have influence on the library expectations.

\section{Research Methodology}

\subsection{Survey questionnaire and pilot test}

The intensive research of previous literature was particularly for the development of meaningful measure of personal information environment, information-seeking attitudes, online information attitudes, barriers to information seeking, retirement expectations, and library expectations. Table 1 explains specific sub-factors of survey questionnaires in the category of each construct.

The survey was proceeded in the method of the self-administered questionnaire survey. Its contents consist of twenty-two indicators (as observed variables) from 6 constructs (as latent variables). The items in the survey were measured on a five-point

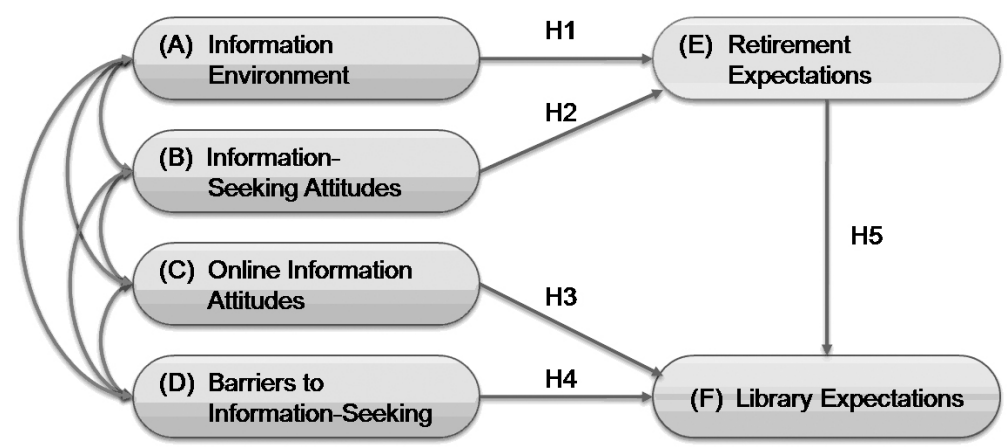

〈Figure 1〉 Conceptual framework of research 
200 Journal of the Korean Society for Information Management, 28(2), 2011

$\langle$ Table 1〉 The structure of key constructs

\begin{tabular}{|c|c|c|c|}
\hline $\begin{array}{l}\text { Constructs } \\
\text { (Latent variables) }\end{array}$ & $\begin{array}{l}\text { Focused topic } \\
\text { (survey setting) }\end{array}$ & $\begin{array}{c}\text { Indicators } \\
\text { (Observed variables) }\end{array}$ & No. \\
\hline \multirow{3}{*}{$\begin{array}{c}\text { (A) } \\
\text { Personal } \\
\text { information } \\
\text { environment }\end{array}$} & \multirow{2}{*}{ Time } & I have enough time for reading materials with my interests. & $(\mathrm{x} 1)$ \\
\hline & & I can collect the information with my interests in the office. & $(\mathrm{x} 2)$ \\
\hline & Space & I have my reading space in the home. & $(\mathrm{x} 3)$ \\
\hline \multirow{4}{*}{$\begin{array}{l}\text { (B) } \\
\text { Information } \\
\text { seeking } \\
\text { attitudes }\end{array}$} & \multirow{2}{*}{$\begin{array}{l}\text { Preparation of } \\
\text { future uncertainty }\end{array}$} & I have interests in information on preparation of retirement. & $(\mathrm{x} 4)$ \\
\hline & & I have interests in practical information for the daily life. & $(\mathrm{x} 5)$ \\
\hline & \multirow{2}{*}{$\begin{array}{c}\text { Sensitivity of } \\
\text { personal interests }\end{array}$} & I have interests in arts \& academic information. & $(\mathrm{x} 6)$ \\
\hline & & I would like to read the classics in leisure time. & $(\mathrm{x} 7)$ \\
\hline \multirow{4}{*}{$\begin{array}{l}\text { (C) } \\
\text { Attitudes } \\
\text { toward online } \\
\text { information }\end{array}$} & $\begin{array}{l}\text { Autonomy of } \\
\text { online information }\end{array}$ & I have an ability to search information what I want on the Internet. & $(\mathrm{x} 8)$ \\
\hline & $\begin{array}{c}\text { Valuation of Web } \\
\text { information } \\
\text { sources }\end{array}$ & Internet will have more influence on my daily life after retirement. & $(\mathrm{x} 9)$ \\
\hline & \multirow{2}{*}{$\begin{array}{l}\text { Perceived } \\
\text { usefulness }\end{array}$} & $\begin{array}{l}\text { I wish to have information search education for the in-depth } \\
\text { understanding of my interests. }\end{array}$ & $(\mathrm{x} 10)$ \\
\hline & & $\begin{array}{l}\text { I wish to do the activities of blog and online-caf? for my personal } \\
\text { interests. }\end{array}$ & $(\mathrm{x} 11)$ \\
\hline \multirow{3}{*}{$\begin{array}{l}\text { (D) } \\
\text { Barriers to } \\
\text { information } \\
\text { seeking }\end{array}$} & \multirow[b]{2}{*}{ Work overload } & My official job blocks me from seeking information with continuity. & $(\mathrm{x} 12)$ \\
\hline & & $\begin{array}{l}\text { My role and duty in daily life blocks me from doing research and } \\
\text { collecting information. }\end{array}$ & $(\mathrm{x} 13)$ \\
\hline & $\begin{array}{l}\text { Information } \\
\text { overload }\end{array}$ & $\begin{array}{l}\text { It is not easy to choose the right information for me in the information } \\
\text { gluts. }\end{array}$ & $(\mathrm{x} 14)$ \\
\hline \multirow{4}{*}{$\begin{array}{l}(\mathrm{E}) \\
\text { Expectations } \\
\text { of the } \\
\text { retirement }\end{array}$} & \multirow{2}{*}{$\begin{array}{c}\text { Intelligent } \\
\text { activities in the } \\
\text { future }\end{array}$} & I have my interesting fields continued even after retirement. & $(\mathrm{x} 15)$ \\
\hline & & I wish to broaden my interesting area after retirement. & $(\mathrm{x} 16)$ \\
\hline & \multirow{2}{*}{$\begin{array}{l}\text { New human } \\
\text { network }\end{array}$} & $\begin{array}{l}\text { I wish to make new friends with people sharing with personal interests } \\
\text { after retirement. }\end{array}$ & $(\mathrm{x} 17)$ \\
\hline & & I will grow with good human-network even after retirement. & $(\mathrm{x} 18)$ \\
\hline \multirow{4}{*}{$\begin{array}{c}(\mathrm{F}) \\
\text { Expectations } \\
\text { of the } \\
\text { libraries }\end{array}$} & Service place & Library should provide service for the baby-boomer group. & $(\mathrm{x} 19)$ \\
\hline & information place & $\begin{array}{l}\text { Library should have enough materials and equipments for people } \\
\text { living in service area. }\end{array}$ & $(\mathrm{x} 20)$ \\
\hline & \multirow[b]{2}{*}{ Social place } & Library should be located with high accessibility for users. & (x21) \\
\hline & & $\begin{array}{l}\text { Library should provide the proper space for cultural activities of people } \\
\text { in the communities. }\end{array}$ & $(\mathrm{x} 22)$ \\
\hline
\end{tabular}

Likert's scale with answers ranging from strongly disagree (1) to strongly agree (5) in order to ensure high statistical variability among the survey response. It means high score is the high agreement on the survey question. The final survey instrument in- corporated feedback received from seven research professionals on survey, which enhanced the clarity of the instrument and exhibited the content validity.

For testing the hypotheses, the researcher utilized the statistical software (e.g., SPSS) verifying SEM 
for factor analyses and path analysis. The reason the researcher chose the SEM- based procedures for testing hypotheses was because this method have substantial advantage over first-generation techniques such as principal components analysis, factor analysis, discriminant analysis, or multiple regression because of the greater flexibility that a researcher had for the interplay between theory and data.

\subsection{Data collection}

After questionnaires design, recruitment of survey took place on a regional basis firstly classified by the working fields. The survey sheets were distributed to total 900 of the baby boomers through proxies of the researcher in various public sectors including army and public corporations from November 1. to December 5. 2009 and collected with total 570 data (the response rate of 63\%) until December 23, 2009. Dropping the cases with missing values and outliers, the final survey data for statistical analysis were total 500 responses $(55 \%)$.

In order to protect anonymity and confidentiality, codes were used throughout. The same code was utilized consistently to represent the same participant. The researcher needed to generate quantitative data to find out some significant relationships between user perceptions, context of life, their information needs and wants.

\section{Model Assessment}

\subsection{Demographic characteristics of the respondents}

The survey comprised the eight primary categories and thirty-four questions including demographic information of the respondents. The mean age of the survey participants was 48 years old and the mean working period of time as a public worker was approximately 23 years.

The following table shows the respondents' social attributes including demographic characteristics and their socio-economic status which may influence what methods they employ for information seeking, searching, and information use, and how successful they may be in their endeavors.

〈Table 2〉 The frequencies of the respondents' characteristics

\begin{tabular}{c|c|c|c|c}
\hline Category & Sub-categories & $\begin{array}{c}\text { Numbers of } \\
\text { respondents }\end{array}$ & $\begin{array}{c}\text { Percent } \\
(\%)\end{array}$ & $\begin{array}{c}\text { Accumulated } \\
(\%)\end{array}$ \\
\hline \multirow{5}{*}{ Working area } & The legislative \& The judicial & 15 & 3 & 3 \\
& The administration & 84 & 16.8 & 19.8 \\
& Local government & 189 & 37.8 & 57.6 \\
& Army \& Police & 91 & 18.2 & 75.8 \\
& The public corporation & 70 & 14 & 89.8 \\
\cline { 2 - 5 } & Others & 51 & 10.2 & 100 \\
\hline
\end{tabular}


202 Journal of the Korean Society for Information Management, 28(2), 2011

\begin{tabular}{|c|c|c|c|c|}
\hline Category & Sub-categories & $\begin{array}{l}\text { Numbers of } \\
\text { respondents }\end{array}$ & $\begin{array}{c}\text { Percent } \\
(\%)\end{array}$ & $\begin{array}{c}\text { Accumulated } \\
(\%)\end{array}$ \\
\hline \multirow{6}{*}{ Age } & $36-40$ & 42 & 8.4 & 8.4 \\
\hline & $41-45$ & 109 & 21.8 & 30 \\
\hline & $46-50$ & 210 & 42 & 72.2 \\
\hline & $51-55$ & 122 & 24.4 & 96.6 \\
\hline & $56-60$ & 17 & 3.4 & 100 \\
\hline & Total & 500 & 100 & \\
\hline \multirow{7}{*}{$\begin{array}{c}\text { Working } \\
\text { period }\end{array}$} & 10 years below & 22 & 4.4 & 4.4 \\
\hline & 11 - 15 years & 41 & 8.2 & 12.6 \\
\hline & $16-20$ years & 129 & 25.8 & 38.4 \\
\hline & 21 - 25 years & 128 & 25.6 & 64 \\
\hline & $26-30$ years & 142 & 28.4 & 92.4 \\
\hline & 31 years over & 38 & 7.6 & 100 \\
\hline & Total & 500 & 100 & \\
\hline \multirow{7}{*}{$\begin{array}{l}\text { Education } \\
\text { level }\end{array}$} & High school graduate & 66 & 13.2 & 13.2 \\
\hline & 2-year college graduate & 34 & 6.8 & 20 \\
\hline & 4-year college graduate & 166 & 33.2 & 53.2 \\
\hline & Master(including enrollment and certificate) & 175 & 35 & 88.2 \\
\hline & Doctor(including enrollment and certificate) & 53 & 10.6 & 98.8 \\
\hline & Others & 6 & 1.2 & 100 \\
\hline & Total & 500 & 100 & \\
\hline \multirow{3}{*}{ Gender } & Male & 413 & 82.6 & 82.6 \\
\hline & Female & 87 & 17.4 & 100 \\
\hline & Total & 500 & 100 & \\
\hline \multirow{3}{*}{$\begin{array}{c}\text { The } \\
\text { baby-boom } \\
\text { generation }\end{array}$} & $1^{\text {st }}$ & 286 & 57.2 & 52.7 \\
\hline & $2^{\text {nd }}$ & 214 & 42.8 & 100.0 \\
\hline & Total & 500 & 100 & \\
\hline
\end{tabular}

\subsection{Confirmatory factor analysis}

Because the structural portion of a full structural equation model involves relations among only latent variables, and the primary concern in working with a full SEM model is to assess the extent to which these relations are valid, it is critical that the measurement of each latent variable is sound (Byrne 2010). Thus, an important step in the analysis of full latent variable model was to test first for the validity of measurement model before any attempt to evaluate the structural model. The researcher fed the coding data into the SEM program for evaluating the measurement model through the confirmatory factor analysis.

\subsubsection{Conformance to expected parameter estimates}

As the results of the 1st confirmatory factor analysis using twenty-two observed variables, statistics was 
501.569 and other parameter estimates were as follows: Degree of freedom (194), P value (0.000), RMR (0.045), RMSEA (0.056), GFI (0.195), AGFI (0.889), PGFI (0.702), NFI (0.837), RFI (0.806), ITI (0.893), TLI (0.871), CFI (0.892), PNFI (0.703), and PCFI (0.749). In the result, most indices such as P, AGFI, PGFI, NFI, RFI, ITI, TLI, CFI, and PCFI could not satisfy the standard level. Thus, utilizing modification Indices for generating the better model fit, the researcher deleted 8 items (x1, x6, x7, x10, x11, x14, $\mathrm{x} 17, \mathrm{x} 18)$ seen in Figure 2.

The measurement model offered an acceptable fit to the data: (76.648), Degree of freedom (62), P (0.100), RMR (0.025), RMSEA (0.022), GFI (0.978), AGFI (0.963), PGFI (0.578), NFI (0.957), RFI (0.937), ITI (0.991), TLI (0.987), CFI (0.991), PNFI (0.652), and PCFI (0.675). After modification, all the key fit statistics showed the significant improvement. Overall, these fit indices indicated a good model fit.

\subsubsection{Reliability of parameter estimates}

In reliability test, the researcher evaluated the standardized $\lambda$ of each item, reliability of construct, Average Variance Expected (AVE) and thus, the detailed result is in Table 3 . The standardized $\lambda$ of each variable was fulfilling as the value of 0.5 $\sim 0.95$, the standard level suggested by Bagozzi and Yi (1988). Though the critical standard of construct reliability was over 0.7 and AVE was suggested as the value over 0.5 , these values were not suggested in SEM measurement program. Even though the standard levels did not satisfy such as construct reliability (0.453) and AVE (0.294), the researcher did not move out the latent variable A (Personal information environment) for the further contextual interpretation of information-seeking behavior.

Validity of the research could be evaluated through test of convergent and discriminant validity. Discriminant validity meant the level of inter-relationships

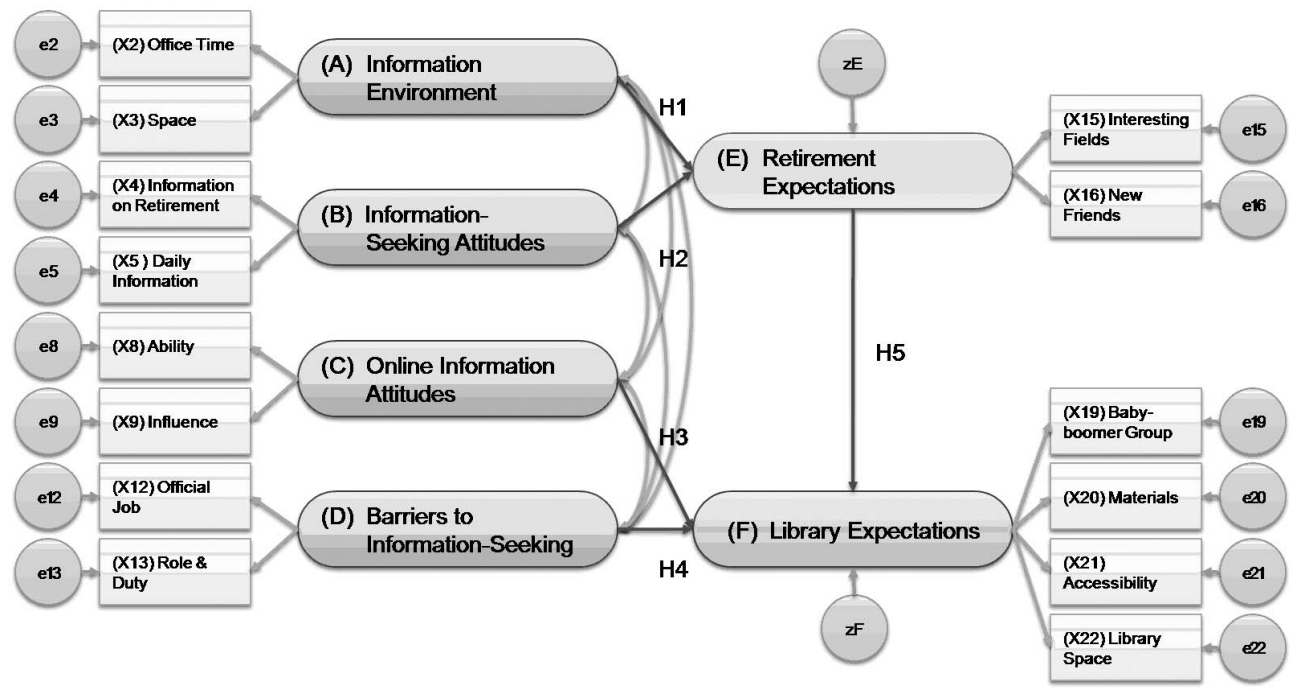

$\langle$ Figure 2〉 The modified research model of SEM 
204 Journal of the Korean Society for Information Management, 28(2), 2011

〈Table 3〉 The result of measurement model analysis

\begin{tabular}{|c|c|c|c|c|c|c|c|}
\hline $\begin{array}{c}\text { Latent } \\
\text { Variables }\end{array}$ & $\begin{array}{l}\text { Observed } \\
\text { Variables }\end{array}$ & $\begin{array}{c}\text { Un-standard } \\
\text { ized } \lambda\end{array}$ & S.E. & C.R. & $\begin{array}{c}\text { Standardized } \\
\lambda\end{array}$ & $\begin{array}{l}\text { Construct } \\
\text { Reliability* }\end{array}$ & $\begin{array}{l}\text { AVE (Average } \\
\text { Variance } \\
\text { Extended) }{ }^{* *}\end{array}$ \\
\hline \multirow{2}{*}{$\begin{array}{c}\text { (A) } \\
\text { Personal } \\
\text { information } \\
\text { environment }\end{array}$} & (x2) Office Time & 1 & - & - & 0.51 & \multirow[b]{2}{*}{0.453} & \multirow[b]{2}{*}{0.294} \\
\hline & (x3) Space & 0.942 & 0.186 & 5.056 & 0.572 & & \\
\hline \multirow{2}{*}{$\begin{array}{c}\text { (B) } \\
\text { Information } \\
\text { seeking } \\
\text { attitudes }\end{array}$} & $\begin{array}{l}\text { (x4) Information on } \\
\text { Retirement }\end{array}$ & 1 & - & - & 0.682 & \multirow{2}{*}{0.665} & \multirow{2}{*}{0.498} \\
\hline & $\begin{array}{c}\text { (x5) Daily } \\
\text { Information }\end{array}$ & 0.861 & 0.088 & 9.796 & 0.729 & & \\
\hline \multirow{2}{*}{$\begin{array}{c}\text { (C) } \\
\text { Attitudes } \\
\text { toward online } \\
\text { information }\end{array}$} & (x8) Ability & 0.651 & 0.082 & 7.94 & 0.638 & \multirow[b]{2}{*}{0.726} & \multirow[b]{2}{*}{0.575} \\
\hline & (x9) Influence & 1 & - & - & 0.862 & & \\
\hline \multirow{2}{*}{$\begin{array}{c}\text { (D) } \\
\text { Barriers to } \\
\text { information } \\
\text { seeking }\end{array}$} & (x12) Official Job & 1 & - & - & 0.848 & \multirow[b]{2}{*}{0.822} & \multirow[b]{2}{*}{0.697} \\
\hline & (x13) Role \& Duty & 0.987 & 0.097 & 10.201 & 0.822 & & \\
\hline \multirow{2}{*}{$\begin{array}{l}\quad(\mathrm{E}) \\
\text { Expectations of } \\
\text { the retirement }\end{array}$} & $\begin{array}{l}\text { (x15) Interesting } \\
\text { Fields }\end{array}$ & 1 & - & - & 0.67 & \multirow[t]{2}{*}{0.661} & \multirow[t]{2}{*}{0.495} \\
\hline & (x16) New Friends & 0.804 & 0.08 & 10.055 & 0.735 & & \\
\hline \multirow{4}{*}{$\begin{array}{l}\qquad(\mathrm{F}) \\
\text { Expectations of } \\
\text { the libraries }\end{array}$} & \begin{tabular}{|c|} 
(x19) \\
Baby-boomer \\
Group \\
\end{tabular} & 1 & - & - & 0.763 & \multirow{4}{*}{0.766} & \multirow{4}{*}{0.453} \\
\hline & (x20) Materials & 0.88 & 0.072 & 12.219 & 0.637 & & \\
\hline & (x21) Accessibility & 0.963 & 0.073 & 13.212 & 0.707 & & \\
\hline & $\begin{array}{c}\text { (x22) Library } \\
\text { Space }\end{array}$ & 0.77 & 0.07 & 11.055 & 0.569 & & \\
\hline
\end{tabular}

between over two measurement tools on the latent factor. The measurement tools were the size of the stancardized $\lambda$, AVE, and the construct reliability displaying in Table 3.

\subsection{Structural model analysis}

The measurement model, which postulates the relationship between observed measures (or indicators) and their constructs, should be reliable and valid in testing (Segars and Grover 1993). Modeling systems of structural relationships between a set of observed variables is referred to as path analysis (Kaplan 2009). As the result of path analysis based on the advanced measurement model, the results of the full model indicated fit indices : (83.934), Degree of freedom (66), P (0.067), RMR (0.029), RMSEA (0.023), GFI (0.976), AGFI (0.963), PGFI (0.614), NFI (0.953), RFI (0.935), ITI (0.990), TLI (0.985), CFI (0.989), PNFI (0.691), and PCFI (0.718). The resulting sta- 
tistics were strong evidence of significant improvement on the overall model fit.

In the next step, the researcher checked the path coefficients and significance after evaluating on the criteria of overall fit with the data and chose whether the research hypotheses were supported or not. The results on structural model are summarized in Table 4: four paths among five ones were significant in the level of $a=0.05$, and only path (Attitudes toward online information $\rightarrow$ Expectations of the libraries) was not supported by SEM measurement.

〈Table 4〉 The result of structural model analysis

\begin{tabular}{c|c|c|c|c|c|c}
\hline \multicolumn{2}{c|}{ Path } & $\begin{array}{c}\text { Standardized } \\
\lambda\end{array}$ & $\begin{array}{c}\text { Standard } \\
\text { Error }\end{array}$ & C.R. $(>1.96)$ & $\mathrm{P}(\langle 0.05)$ & Assessment \\
\hline $\begin{array}{c}\text { Personal information } \\
\text { environment }\end{array}$ & $\begin{array}{c}\text { Expectations of the } \\
\text { retirement }\end{array}$ & 0.375 & 0.109 & 3.941 & $* * *$ & Significant \\
\hline $\begin{array}{c}(\mathrm{B}) \\
\text { Information seeking } \\
\text { attitudes }\end{array}$ & $\begin{array}{c}\text { Expectations of the } \\
\text { retirement }\end{array}$ & 0.564 & 0.083 & 6.861 & $* * *$ & Significant \\
\hline $\begin{array}{c}(\mathrm{E}) \\
\text { Expectations of the } \\
\text { retirement }\end{array}$ & $\begin{array}{c}\text { Expectations of the } \\
\text { libraries }\end{array}$ & 0.355 & 0.064 & 5.142 & $* * *$ & Significant \\
\hline $\begin{array}{c}(\mathrm{C}) \\
\text { Attitudes toward } \\
\text { online information }\end{array}$ & $\begin{array}{c}\text { Expectations of the } \\
\text { libraries }\end{array}$ & 0.053 & 0.054 & 0.843 & 0.399 & Significant \\
\hline $\begin{array}{c}(\mathrm{F}) \\
\text { Barriers to information } \\
\text { seeking }\end{array}$ & $\begin{array}{c}\text { Expectations of the } \\
\text { libraries }\end{array}$ & 0.294 & 0.049 & 5.045 & $* * *$ & Significant \\
\hline
\end{tabular}

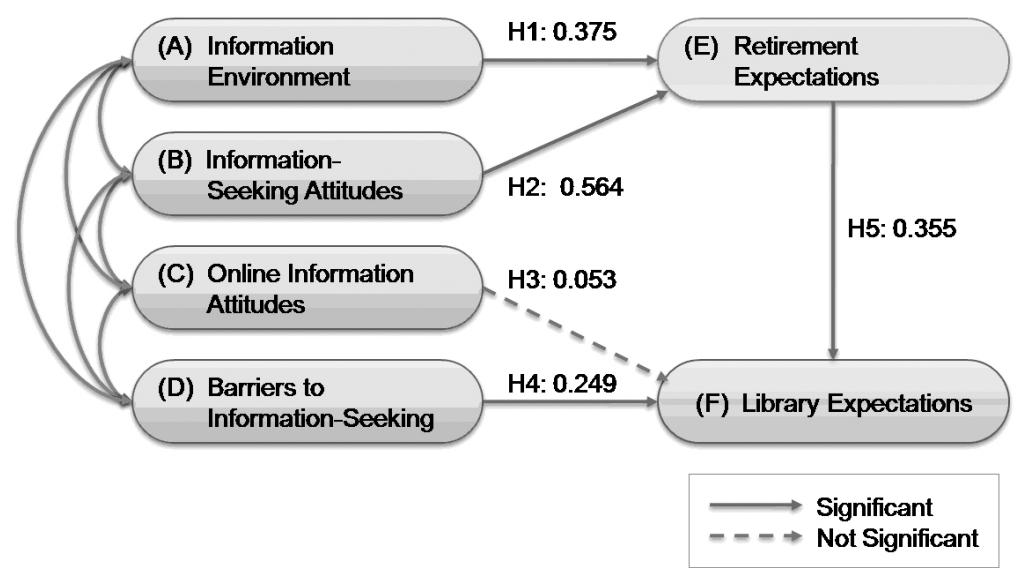

〈Figure 3〉 Path diagram of research model 
Effects and assessment of hypotheses in the research model were as below.

H1: Personal information environment has influence on the retirement expectations. (supported)

$\mathrm{H} 2$ : Information-seeking attitudes have influence on the retirement expectations. (supported)

H3: Online information attitudes have influence on the library expectations. (Not supported)

$\mathrm{H} 4$ : Barriers to information seeking have influence on the library expectations. (supported)

H5: The retirement expectations have influence on the library expectations. (supported)

\section{Conclusion and Implications}

\subsection{Conclusion}

The researcher found in this study that it was the time for libraries to expand their role in response to the changing information preference and needs of user group in the aging society. As short time horizons on human's lifespan tended to restrict the patterns of information-seeking behavior, the limited and routine service scope on traditional user group would restrict the possibility and role of libraries in society. In this sense, this study presented some of information issues related with massive retirement and after-retirement life of the baby-boomers, who would emerge as dominant group in the future society worldwide.

The researcher started the study by investigating the information-seeking behaviors of baby-boomers preparing for retirement. this study empirically tested research model for holistic understanding of the information behavior of pre-retirees. The findings through developing model based on testing the quantitative data were as follows: there were significant relationships between expectations of the retirement and personal information contexts such as personal information environment and information-seeking attitudes. Also the researcher recognized the relationships between barriers to information seeking and expectations of the libraries through SEM testing. The factor of the retirement expectations in the model played the noteworthy role as mediated variable between personal information context and library expectations. Finally, the research discovered the relationships among personal information environment, life contexts including the retirement, and social interaction with respect to information-seeking behaviors of baby-boomers.

\subsection{Implication}

This study shows the importance of learning about the rarely studied segment of users to generate guidelines for libraries in the future. The baby boomers as pre-retirees have diversified information need to manage their daily life in an unpredictable future. The boomers' retirements in society will increase the amount of retirees with higher education and those with a more serious retirement plan. The society as a whole would benefit by continuing to have the retirees as active participants of the community without losing their experience. 
This study began to investigate the ways for libraries to help people in their 50s tofind the information needed in their lives, even after retirement. Fundamentally, we wanted to find the social role that libraries will play in the upcoming aged society. The researcher started the study by investigating the information seeking behavior of baby boomers preparing for retirement. We collected data through intensive interviews with public sector workers in the 50 s age group to understand their information need contexts and the actual needs. Some of our findings included that the pre-retirees' personal information seeking behavior was formulated based on their information needs relating to their unique values and long-term plans. Their information interests were individually driven and, at the same time, built based on the work experiences in their life contexts.

Based on this study, the researcher suggested several areas of great research potential (the results of which will help people and library practitioners un- derstand more about human information behaviors): focusing on the emerging potential adult user groups, discovering role of library place interacting with other people in the sense of community, exploring forms of serious leisure and interest of retirees.

Professionals need to have more research done to identify and map human information behaviors across the life cycle. The researcher hopes that this study can have a contribution to uncover the broader contexts of the baby-boomers' information behavior in local settings by elaborating on more elements of their information world in the daily life. We can then expect a greater variety of interdisciplinary works on creatively responding to the aging issue and be able to develop sensitive and effective public-policy measures. As practitioners in the Library and Information Science field and society members, it is our goal to help assure the best possible quality of life across the lifespan through the provision of information to the people.

\section{References}

Atton, H. 1985. "Psychology of retirement." British Journal of Occupational Therapy, 48: 375-378.

Bawden, David and Lyn. Robinson. 2009. "The dark side of information: overload, anxiety, and other paradoxes and pathologies." Journal of Information Science, 35(2): 180-191.

Byrne, Barbara M. 2010. Structural Equation Modeling with AMOS: Basic Concepts, Application, and
Programming. New York: Taylor and Francis Group.

Cook, C. and F. Heath. 2001. 'Users' perceptions of library service quality: a LibQUAL ${ }^{+\mathrm{TM}}$ : Qualitative interview study." Library Trends, 49: 548-584.

Davis, F. D. 1989. "Perceived usefulness, perceived ease of use, and user acceptance of information 
technology." MIS Quarterly, 13(3): 318-341.

Dervin, B. 1992. "From the mind's eye of the user: the sense-making qualitative-quantitative methodology.” In J.Glazier \& R. Powell(Eds.), Qualitative Research in Information Management, 61-84. Englewood, CO: Libraries Unlimited.

Fretz, B. R, N. A. Kluge, Johns S.M. Ossana, and M. W. Merikangas. 1989. "Intervention targets for reducing preretirement anxiety and depression." Journal of Counseling Psychology, 36(3): 301-307.

Gee, S. and J. Baillie. 1999. "Happily ever after? An exploration of retirement expectations." Educational Gerontology, 25(2): 109-128.

Han, Heeja. 2002. "An analysis on the expectation factors of life change after retirement." Korea Gerontological Nursing, 4(2): 195-206.

Hargittai, E. 2003. How wide a web? Inequalities in accessing information online. Princeton: Sociology Department, Princeton University.

Hargittai, E. and A. Hinnabt. 2006. "Toward a social framework for information seeking." In Spink, A., and Cole, C. (Eds.), New directions in human information behavior. Dordrecht, Netherlands: Springer.

Hunter, Wendy, Wei Wang, and Anthony Worsley. 2007. "Retirement planning and expectations of Australian babyboomers." Annals of the New York Academy of Sciences, 1114: 267-278.

Jopsen, D. A. 1989. “Antecedent events to adolescent career decision processes." Guidance and Counseling, 4: 5-14.
Julien, Heidi E. 1999. 'Barriers to Adolescents' Information seeking for career decision making." Journal of the American Society for Information Science, 50(1): 38-48.

Lee, Jeongin. 2003. "An analysis on the depression and life satisfaction of the middle-aged men." Journal of Korea Academy of Adult Nursing, 15(3): 422-431.

Lee, Sojeong. 2009. "The characteristics of old age preparation of Korea adults and policy implications." Health Welfare Policy Forum, 2009(1): 72-85.

Nahl, Diane and Dania. Bilal. 2007. Information and Emotion: the emergent affective paradigm in information behavior research and theory. New York: ASIS\&T.

Oldenberg, Ray. 1999. The Great Good Place: cafes, coffee shops, bookstores, bars, hair salons, and other hangouts at the heart of a community. New York : Marlowe \& Company.

Segars, A. H. and V. Grover. 1993. "Re-examining perceived ease of use and usefulness: a confirmatory factor analysis." MIS Quarterly, 17(4): 517-525.

Spink, A. and C. Cole. 2001. "Information and poverty: information-seeking channels used by African American low-income households." Library \& information Science Research, 23: 45-65. Spink, A. and C. Cole. 2006. New directions in human information behavior. Dordrecht, Netherlands: Springer. 